\title{
Bentuk Partisipasi Masyarakat Dalam Program PLP-BK Di Kelurahan Kedung Cowek
}

\author{
Rio Anang Hadi dan Ema Umilia \\ Perencanaan Wilayah dan Kota, Fakultas Arsitektur Desain dan Perencanaan \\ Institut Teknologi Sepuluh Nopember (ITS) \\ e-mail: rioahahahahah@gmail.com danumilia84@gmail.com
}

\begin{abstract}
Abstrak-Permasalahan permukiman kumuh harus diperhatikan secara penuh oleh pemerintah, dikarenakan masyarakat miskin juga mempunyai hak untuk memiliki taraf hidup yang lebih baik,akan tetapi masyarakat seolah tidak memiliki rasa kepercayaan baik kepada pemerintah maupun program yang diberikan pemerintah, hal inilah yang menjadi pokok utama ketidak berhsilan program perbaikan permukiman yang sudah dilakukan, pada penelitian ini penulis ingin mengetahui apasaja bentuk partisipasi masyarakat yang dilakukan dalam setiap tahapan program PLP-BK di Kelurahan Kedung Cowek. Dengan mengunakan teknik analisis deskriptif kualitatif penulis berharap menemukan dan menjabarkan apasaja bentuk pasrtisipasi masyarakat dalam setiap tahapan PLP-BK. Dan ternyata hasil dari analisi bentuk partisipasi masyarakat dalam setiap tahap program PLP-BK dapat dikatakan kurang, masyarakat dirasa kurang aktif dalam program tersebut. Pada tahap sosialisasi masyarakat mau menghadiri tahap sosialisasi dikarenakan ada acara keagamaannya, sedangkan pada tahap perencanaan, masyarakat hanya menyumbang bentuk partisipasi buah pikiran, pengambilan keputusan dan perwakilan saja, dan pada tahap pelaksanaan pembangunan dan tahap kebrelanjutan masyarakat tidak menyumbangkan bentuk partisipasi apapun, dikarenakan masyarakat tidak dilibatkan dalam kedua tahap tersebut.
\end{abstract}

Kata Kunci-Bentuk Partisipasi, Program PLP-BK, Keterlibatan.

\section{PENDAHULUAN}

$\mathrm{P}$ ERMUKIMAN kumuh adalah masalah bagi pemerintah, dalam hal mengurangi permukiman kumuh yang ada di Indonesia, pemerintah menargetkan bahwa pada tahun 2019 permukiman kumuh akan dikurangi sampai 0\%, dengan melakukan program-program perbaikan permukiman yang bersifat partisipatif, hal ini termasuk dalam program Rencana Pembangunan Jangka Menengah Nasional yang dicanangkan oleh pemerintah untuk mengurangi angka kekumuhan yang ada di kota-kota yang ada di Indonesia [1].

Kota Surabaya termasuk memiliki kawasan permukiman kumuh yang cukup luas, kota Surabaya teridentifikasi memiliki kawasan kumuh sebesarv 582,3 hektar yang tersebar diseluruh pelosok kota Surabaya [2]. Pemerintah kota Surabaya sudah mencoba untuk mengurangi permukiman kumuh yang ada dengan menyelenggarakan program perbaikan permukiman seperti program KIP (Kampong Improvement Program), RSDK (Rehabilitasi Sosial Daerah Kumuh), P2KP PNPM Mandiri akan tetapi program tersebut tidak dirasa tidak berhasil [3], pada tahun 2014 di kota Surabaya diselenggarakan program baru dengan nama program PLP-BK (Penataan Lingkungan
Permukiman Berbasis Komunitas) yang dimana program ini mempunyai tujuan merubah pola pikir masyarakat menuju masyarakat yang madani [4]. Program ini diselenggarakan pada 7 kelurahan yang ada di kota Surabaya, dengan memilih kelurahan paling kumuh yang ada di Surabaya, yang salah satunya adalah kelurahan Kedung Cowek [5]

Kelurahan Kedung Cowek termasuk dalam berberapa dokumen kelurahan kumuh milik kota Surabaya seperti dokumen SK walikota maupun dokumen Rencana Kawasan Permukiman Kumuh Perkotaan (RKP-KP) kota Surabaya, maka pantaslah kelurahan ini menerima program PLP-BK agar kelurahan ini terbebas dari kekumuhan [6]. Program PLP-BK adalah program yang bersifat partisipatif dimana seluruh masyarakat dituntut untuk ikut serta dalam profram ini [7]. Pada penelitian sebelumnya dalam program GPO-BA (Global Partneship Output-Based Aid diketahui partisipasi mayarakat sangat rendah dalam program ini, padahal program ini juga bersifat partisipatif [8]. Maka perlu dilakukan penelitian untuk mengetahui apakah program PLP-BK yang diselenggarakan di Kelurahan Kedung Cowek berhasil meningkatkan partisipasi masyarakat atau sama saja dengan program perbaikan permukiman sebelumnya yang dirasa gagal menarik minat masyarakat untuk berpartisipsi.

\section{METODE PENELITIAN}

\section{A. Jenis dan Pendekatan Penelitian}

Pendekatan yang digunakan dalam penelitian ini dengan menggunakan metode deskriptif kualitatif, guna mengetahui dan menjabarkan secara jelas kondisi partisipasi masyarakat dalam program PLP-BK di Kelurahan Kedung Cowek.

\section{B. Variabel Penelitian}

Penelitian ini menggunakan 8 variabel mengenai bentuk partisipasi masyarakat, yaitu bentuk partisipasi berupa tenaga, buah pikiran, pengambilan keputusan, keterampilan, uang, harta benda dan perwakilan/representatif.

\section{Pengumpulan Data}

Data-data dalam penelitian ini bersumber dari survei instansi dan studi literatur sebagai data dasar yang diperkaya dengan observasi lapangan serta wawancara untuk memeperdalam informasi terkait bentuk partisipasi masyarakat dalam pertahapan program PLP-BK di Kelurahan Kedung Cowek. 


\section{Mengetahui semua tahapan program PLP-BK.}

Dalam program PLP-BK terdapat 4 program yaitu :

\section{1) Tahap Sosialisasi}

Pada tahap ini, lebih menonjol kegiatan sosialisasi program PLP - BK kepada masyarakat setempat dan juga masyarakat/BKM setempat juga menyiapkan sendiri TAPP (Tenaga Ahli Perencanaan Partisipatif dan Pemasaran) dan juga TIPP (Tim Inti Perencanaan dan Pemasaran) guna mendampingi masyarakat dalam melakukan kegiatan-kegiatan selanjutnya dalam program PLP - BK

\section{2) Tahap perencanaan}

Pada tahap ini masyarakat melakukan rembug dalam tingkat kelurahan dan didampingi oleh tim ahli dan juga pihak-pihak terkait dalam melakukan pemetaan swadaya, dimana masyarakat dituntut untuk peka dengan potensi dan masalah pada kawasan permukiman mereka, bukan hanya fisik lingkungan saja tetapi juga memasukan unsur-unsur sosial dan ekonomi . Setelah melakukan pemetaan swadaya terkait potensi dan masalah yang terjadi di lingkungan setempat maka hasil usulan-usulan warga tersebut nantinya akan dikumpulkan dalam dokumen RTPLP (Rencana Tindak Penataan Lingkungan Permukiman) pada kawasan tersebut.

\section{3) Tahap pelaksanaan pembangunan}

Dimana pelaksanaannya dipegang oleh KSM (Kelompok Swadaya Masyarakat) setempat, pada tahap ini warga setempat diharuskan ikutserta dalam pelaksanaannya namun ada pengecualian partisipasi warga dimana menurut Pedoman Teknis PLP - BK menyebutkan bahwa ada pekerjaan berat yang tidak mampu dilaksanakan oleh warga setempat disini kegiatan pembangunan yang bersifat berat dilaksanakan oleh pihak konsultan yang dikehendaki

\section{4) Tahap Keberlanjutan}

Pada tahap ini masyarakat setempat melakukan monitoring dan evaluasi terkait pekerjaan yang sudah dilakukan di wilayahnya dan akan diadakan rembug warga di tingkat kelurahan guna pemaparan hasil evaluasi dan pada tahap ini juga sejauhmana masyarakat mampu menjaga hasil pembangunan yang sudah dilakukan di wilayahnya.

Tabel 1. variabel dan indikator dalam tahapan program PLP-BK

\begin{tabular}{ll}
\hline \multicolumn{1}{c}{ Indikator } & \multicolumn{1}{c}{ Variabel } \\
\hline Tahap sosialiasi & Pemberian informasi \\
Tahap & Perencanaan Parsitipatif \\
Perencanaan & \\
Tahap & Pelaksanaan Kontruksi \\
pelaksanaan & \\
pembangunan & \\
Tahap & Monitoring dan evaluasi program \\
keberlanjutan & \\
\hline \hline
\end{tabular}

E. Analisis Bentuk Partisipasi Masyarakat Dalam Tahapan Program PLP-BK

Setelah mengetahui tahapan-tahapan dalam program PLP-BK, dilakukan wawancara in-depth interview dengan menggunakan metode purposive sampling dengan memilih responden yang dianggap ahli lalu degan teknik analisa deskriptif kualitatif guna mengetahui dan menjabarkan bentuk partisipasi masyarakat dalam tahapan PLP-BK di Kelurahan Kedung Cowek

Tabel 2

Bentuk Partisipasi Masyarakat Dalam Tahapan Program PLP-BK Di Kelurahan Kedung Cowek

\begin{tabular}{|c|c|c|}
\hline No & Tahapan PLP-BK & Bentuk Partisipasi Yang Dilakukan \\
\hline 1 & Tahap Sosialisasi & $\begin{array}{l}\text { Dalam tahap sosialisasi program PLP-BK } \\
\text { bentuk partisipasi yang paling dominan adalah } \\
\text { partisipasi tenaga, dikarenakan masyarakat } \\
\text { tertarik dengan acara pengajian akbar yang } \\
\text { diselenggarakan program PLP-BK }\end{array}$ \\
\hline 2 & Tahap Perencanaan & $\begin{array}{l}\text { Pada tahap perencanaan bentuk partisipasi } \\
\text { masyarakat yang paling dominan adalah bentuk } \\
\text { partisipasi berupa buah pikiran, pengambilan } \\
\text { keputusan dan representatif / perwakilan }\end{array}$ \\
\hline 3 & $\begin{array}{l}\text { Tahap pelaksanaan } \\
\text { Pembangunan }\end{array}$ & $\begin{array}{l}\text { Tidak ada bentuk partisipasi karena masyarakat } \\
\text { tidak diikut sertakan dalam tahap pelaksanaan } \\
\text { pembangunan }\end{array}$ \\
\hline 4 & $\begin{array}{l}\text { Tahap } \\
\text { Keberlanjutan }\end{array}$ & $\begin{array}{l}\text { Tidak ada bentuk partisipasi karena masyarakat } \\
\text { tidak dilibatkan pada tahap ini }\end{array}$ \\
\hline
\end{tabular}

Dalam menganalisis bentuk partisipasi bentuk partisipasi masyarakat dalam setiap tahapan program PLP-BK, hanya ada tahap sosialisasi dan tahap perencanaan saja. Sedangkan dalam tahapan pelaksanaan pembanguanan dan tahap keberlanjutan masyarakat di Kelurahan Kedung Cowek belum mencapai tahapan tersebut terkait partisipasi bentuk partisipasinya karena masyarakat memang tidak dilibatkan.

\section{KESIMPULAN}

Penelitian ini bertujuan untuk mengetahui bentuk partisipasi masyarakat dalam setiap tahap program PLP-BK, dan dengan kesimpulan berikut ini :

1. Pada tahap sosialisasi, bentuk partisipasi yang paling dominan adalah bentuk partisipasi Tenaga, dikarenakan masyarakat merasa tertarik dengan acara keagamaan yang dilakukan program PLP-BK, masyarakat sampai turut serta membantu pelaksanaan acara keagamaan tersebut dengan membantu segala persiapan yang demi kelancaran acara keagamaan tersebut, akan tetapi perihal sosialisasi program PLP-BK di Kelurahan Kedung Cowek tidak tersampaikan.

2. Pada tahap perencanaan, bentuk partisipasi yang paling dominan adalah bentuk partisipasi buah pikiran, pengambilan keputusan dan perwakilan/representatif, hal ini didasari dari wawancara yang telah dilakukan kepada masyarakat di Kelurahan Kedung Cowek yang menyebutkan bahwa partisipasi masyarakat seperti buah pikiran dan pengambilan keputusan diwakilkan kepada tokoh-tokoh masyarakat di daerah tersebut, hal ini berbanding terbalik jika mengetahui tujuan utama program PLP-BK adalah partisipasi penuh dari semua masyarakat

3. Bentuk partisipasi masyarakat dalam tahap pelaksanaan program dan juga tahap keberlanjutan tidak ada bentuk partisipasi masyarakat sama sekali, dikarenakan masyarakat hanya diikutsertakan pada tahap sosialisasi program dan tahap perencanaan saja, masyarakat tidak 
dilibatkan dalam tahap-tahap selanjutnya dalam program PLP-BK

\section{DAFTAR PUSTAKA}

[1] L. Faradina, "Tingkat Partisipasi masyarakt terhadap program GPO-BA (Global Partnershipon Output-Based Aid,” 2009.

[2] D. J. C. Karya, Petunjuk Teknis- Program Penataan Lingkungan Berbasis Komunitas. Jakarta, 2014.

[3] D. J. C. Karya, Peodoman Teknis PLP-BK. Jakarta, 2012.
[4]

B. P. Statistik, Kecamatan Bulak Dalam Angka 2017. Surabaya: BPS Kota Surabaya, 2017.

[5] B. S. Nasional, Tata cara perencanaan lingkungan perumahan di perkotaan. 2004

[6] L. Moleong, Metode Penelitian Kualitatif. Bandung: Remaja Rosda Karya, 2007.

[7] Hamijoyo, Partisipasi dalam Pembangunan. Jakarta: Depdikbud RI, 2007.

[8] S. Holil, Partisipasi Sosial dalam Usaha Kesejahteraan Sosial. Bandung: Badan penelitian dan pengembangan sosial, 1980. 